\title{
FACTORS AFFECTING APPLYING LEVEL OF BIOSECURITY ACTIVITIES IN BROILER FARMS IN MATROUH GOVERNORATE, EGYPT
}

\author{
Soha M. Eldeeb* and Dalia E. Abozied \\ Department of Economic Studies, Socio-Economic Studies Division, \\ Desert Research Center, El-Matareya, Cairo, Egypt \\ *E-mail: dr_soha11@yahoo.com
}

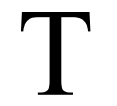

he present research work aimed to determine the factors affecting applying level of biosecurity activities in broiler farms in Matrouh Governorate. This research depended on two sources of data secondary and primary data, the research employed surveyed data of 65 broiler farms. The research was based on the descriptive and quantitative analyses by using some economic indicators, general trend equations and analyzing the simple regression. This research identified the level of biosecurity activities already applied by respondents, and the respondents and farm characteristics that influence this level of applicable biosecurity activities. This research developed the measurement of applying a level of biosecurity activities and then used these measures as dependent variables in identifying the factors that affect the level of applying biosecurity activities. The dependent variable was an aggregated biosecurity score, which ranked and aggregated respondents applying biosecurity activities of 36 biosecurity subindicators. The analysis indicated that older, more educated respondents with larger families and respondents with non-poultry sources of income were more likely to apply a better level of biosecurity activities. The farm characteristics that may influence applying level of biosecurity activities were farm area, distance to neighbours' poultry farm, distance to road and the number, average capacity of farms was also important.

Keywords: chickens, diseases, isolation, farm characteristics

Poultry health management is the emerging issue along with biosecurity measure. Livestock and poultry birds are major causes of zoonotic diseases transmission chain. The food from livestock sources needs to be free from disease-causing agents to safeguard public health. Farm to fork chain must be clean and hygienic. Therefore, biosecurity is foremost important to poultry farmers. It reduces losses in long terms. It promotes organic farming in the rural area. Biosecurity measures, poultry farm 
management and organic farming, become sustainable development cycle in the rural area. Farmers used to keep few birds in scavenging system in villages and have been keeping the native chicken in backyards. Therefore, there is a chance of spreading of poultry disease in livestock and human population due to close contact. It should be avoided for better sanitation practices in the long run. There is a tremendous growth of poultry farming in the last six decades, and it creates income generation in urban and per-urban area (Bhattarai, 2008). The demand for poultry meat has increased due to tourism and changing food habits. The importance of poultry to the national economy cannot be overemphasized, as it has become a popular industry for the small-holders that have great contribution to the economy of the country. The poultry industry is a vital sector to improve agricultural growth and the diet of people, and this sector is important particularly as it serves as one of the major sources of daily protein and nutritional supply (Banshi, 2010).

Egypt is considered one of the developing countries suffering from the problem of overpopulation, which causes a shortage of animal production to satisfy the increased needs of the food goods and the animal protein. So, Egypt is considered one of the countries that have no advantage in producing red meat because of the lack of available green farms in addition to the limited cultivated areas. Therefore, the more attention to the poultry fatness sector becomes a necessity specifically in this stage. It becomes one of the entries to achieve the essence of food security and economic development in the Egyptian agricultural sector.

Biosecurity can be defined as the exclusion, eradication and effective management of risks posed by pests and diseases to the economy, environment and human health. Risk management of biological hazards such as pests, pathogens and diseases can be broadly divided into actions to take place before the biological hazard has materialised (preventive measures) and those taking place during an outbreak (eradication or control), which aim at reducing the consequences in the presence of the hazard (control or adaptation). However, biosecurity is a weakest link public good, where the total amount of protection approximately equals the level of the weakest provider. It matters little that everyone else in the production chain undertakes high biosecurity if one of the key agents (the weakest link) does little to prevent the entry of diseases. Hence, incentives for high biosecurity in production systems should be built into appropriate policies.

Biosecurity has three major components: isolation, traffic control and sanitation. Whenever there is an import of new chicks from abroad, it will be quarantined for three weeks in respective farms. Sick birds will be kept in isolation. Different age and sex groups shall be placed separately to minimize the risk of disease spread. Poultry health management and treatment procedure will better organize employing isolation. The possible breakdowns in biosecurity norms and the introduction of new birds and traffic pose the highest risk to bird health. Therefore, properly managing Egyptian J. Desert Res., 68, No. 2, 173-186 (2018) 
these two factors should be a top priority on a farm. In order to assess how much biosecurity is practical on a farm, following factors such as economics, common sense and relative risk should be considered. New birds represent a high risk to biosecurity because their disease status is unknown. They may have an infection or be susceptible to an infection that is already present in birds that appear normal (healthy carriers) on a farm. While all-in/all-out management system is not feasible for many breeding farms or farms raising exotic fowl or game-birds, it is possible to maintain a separate pen or place to isolate and quarantine all new, incoming stock from the resident population. Isolation pens should be as far from the resident birds as possible. At least three weeks of quarantine is preferable; four weeks is better. Observation of birds for any signs of illness shall be observed regularly. Diagnostic blood tests for infectious diseases shall perform at this time. Avoid putting new birds, including baby chicks, in contact with droppings, feathers, dust and debris left over from previous flocks. Some disease-causing organisms die quickly; others may survive for long periods. Footwear should be disinfected at each site. Disinfectant footbaths may help to decrease the dose of organisms on boots. However, because footbaths can be hard to maintain it correctly is a good idea to have a supply of cleanable rubber boots or strong-soled plastic boots for visitors. It is advisable to wash hands after handling birds in isolation or birds of different groups. It is mandatory to disinfect drinkers and feeders on a regular basis (daily). Plan periodic clean-out, clean-up and disinfection of houses and equipment, at least once in each production cycle of poultry bird. Use this time to institute rodent and pest control procedures. Drying and sunlight are very effective in killing many disease-causing organisms. Dispose of dead birds promptly by rendering, burning, burying, composting or sending to a sanitary landfill.

The objective of the present study were to (1) calculate a scoring system for every farm to present the applicable level of biosecurity activities, (2) identify the farm and respondents characteristics and (3) determine the farm and respondents characteristics that affect the applicable level of biosecurity activities on broiler farms.

\section{METHODOLOGY}

This research was carried out in Matrouh governorate, research depended on two sources of data published data of the Ministry of Agriculture, Economic Affairs Sector, Bulletins of Agricultural Economics and primary data. This involved the use of an interview schedule with a well designed structured questionnaires administered to the respondents, these respondents were randomly selected, a total of 65 farms were selected randamly from all working broiler farms in Matrouh in Febrouary 2018 and interviewed for the research. Data was collected that allowed to make the 
measurement, which represented the farms of appropriate level of biosecurity activities. The survey collected data regarding the respondents' management practices at seven stages within the farm and then scored their activities concerning the effectiveness of reducing disease entry, movement around the farm and ability of the disease to move from the farm. Each farm received a score for each of the following seven stages.

- Farm inputs

- Traffic onto farm

- Biosecurity at a farm gate

- Biosecurity between farm gate and shed

- Biosecurity at the shed door

- Traffic into the shed

- A sensitivity of the broiler flock.

The biosecurity indicator was calculated by summing the biosecurity stage scores. This is a simple method and makes no comparison concerning the importance of each stage in influencing on-farm biosecurity, and this variable is then used as the dependent variable in the simple regression analysis, which identifies farm and respondent characteristics affect the appropriate level of biosecurity activities.

Matrouh governorate was selected as a research area, the main considerations in selecting this research area were as follows: (1) a large number of poultry farms were raised in the region, (2) no study of this nature was conducted previously and (3) satisfactory co-operation received from the poultry farm owners.

\section{RESULTS AND DISCUSSION}

Table (1) and Fig. (1) show that, the total number of working broiler farms in Egypt, desert governorates and Matrouh levels changed from year to another during $2000-2016$. The average number of working broiler farms at Egypt level was about 16781 farms, the average number of working broiler farms at desert governorates level was about 795 farms and the average number of working broiler farms at Matrouh level was about 236 farms. The average number of working broiler farms at Matrouh level reached about $29.6 \%$ of the average number of working broiler farms at desert governorates level during $2000-2016$.

Egyptian J. Desert Res., 68, No. 2, 173-186 (2018) 
Table (1). Development of working broiler farms during 2000 -2016.

\begin{tabular}{cccc}
\hline Year & $\begin{array}{c}\text { Total number of } \\
\text { working broiler } \\
\text { farms at Egypt } \\
\text { level }\end{array}$ & $\begin{array}{c}\text { Total number of } \\
\text { working broiler } \\
\text { farms at desert } \\
\text { governorates level }\end{array}$ & $\begin{array}{c}\text { Total number of } \\
\text { working broiler } \\
\text { farms at } \\
\text { Matrouh level }\end{array}$ \\
\hline $\mathbf{2 0 0 0}$ & 12288 & 404 & 83 \\
$\mathbf{2 0 0 1}$ & 12838 & 423 & 96 \\
$\mathbf{2 0 0 2}$ & 13526 & 429 & 101 \\
$\mathbf{2 0 0 3}$ & 14972 & 533 & 101 \\
$\mathbf{2 0 0 4}$ & 15668 & 544 & 94 \\
$\mathbf{2 0 0 5}$ & 16289 & 684 & 99 \\
$\mathbf{2 0 0 6}$ & 17458 & 897 & 276 \\
$\mathbf{2 0 0 7}$ & 16226 & 774 & 283 \\
$\mathbf{2 0 0 8}$ & 17812 & 846 & 289 \\
$\mathbf{2 0 0 9}$ & 17140 & 848 & 311 \\
$\mathbf{2 0 1 0}$ & 14707 & 541 & 133 \\
$\mathbf{2 0 1 1}$ & 16497 & 649 & 188 \\
$\mathbf{2 0 1 2}$ & 18939 & 1027 & 362 \\
$\mathbf{2 0 1 3}$ & 18920 & 1042 & 321 \\
$\mathbf{2 0 1 4}$ & 20234 & 1135 & 446 \\
$\mathbf{2 0 1 5}$ & 21097 & 1315 & 510 \\
$\mathbf{2 0 1 6}$ & 20678 & 1439 & 236.2 \\
\hline Average & 16781.7 & 795.8 & $\mathbf{2 9 . 6}$ \\
\hline $\mathbf{0}$ & & & \\
\hline
\end{tabular}

Source: Ministry of Agriculture and Land Reclamation, Economic Affairs Sector, $a$ bulletin of Agricultural Economics, different issues.

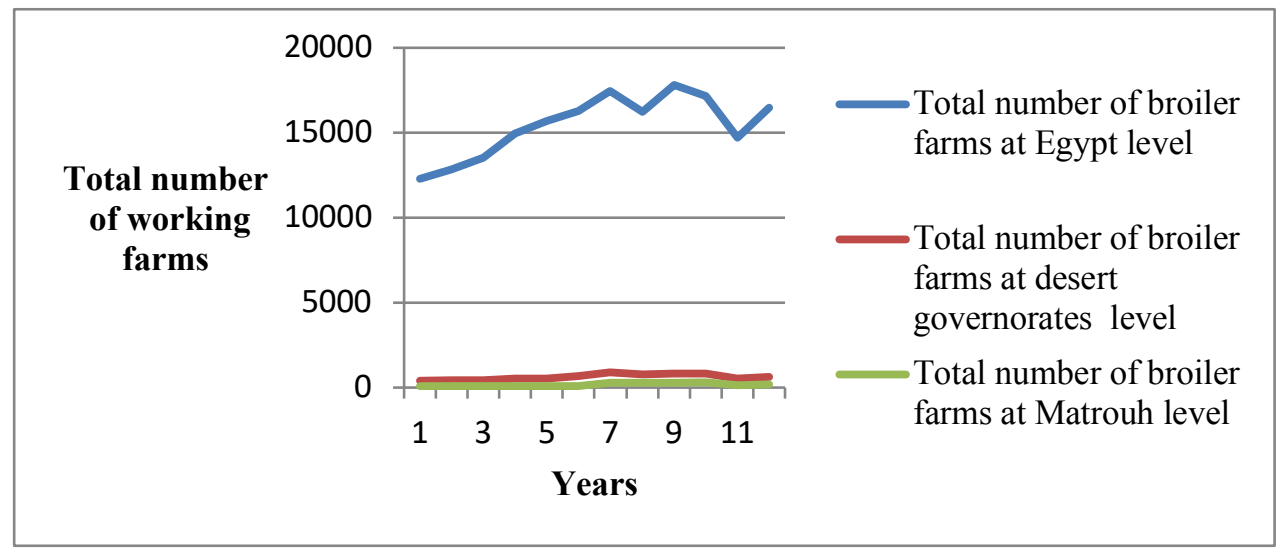

Source: table (1)

Fig. (1). Development of working broiler farms during (2000 -2016).

As shown in the data in table (2) that, the total number of working broiler farms in Egypt level was increasing at a statistically significant rate

Egyptian J. Desert Res., 68, No. 2, 173-186 (2018) 
by 476 farms annually. The total number of working broiler farms at desert governorates level was increasing at a statistically significant rate by 55 farms annually and the total number of working broiler farms at Matrouh level was increasing at a statistically significant rate by 23 farms annually.

Table (2). The General Trend Equations of the development of working broiler farms during (2000 -2016).

\begin{tabular}{lccccc}
\hline Variable & Constant & $\boldsymbol{B}$ & $\begin{array}{c}\text { R Value } \\
\text { \& Sig., }\end{array}$ & \multirow{2}{*}{$\mathbf{R}^{2}$} & F \\
\cline { 3 - 5 } $\begin{array}{l}\text { Total number of working broiler farms at } \\
\text { Egypt level }\end{array}$ & 12501.2 & 475.5 & 8.3 & 0.82 & 68.8 \\
\hline $\begin{array}{l}\text { Total number of working broiler farms at } \\
\text { desert governorates level }\end{array}$ & 299.6 & 55.1 & 7.3 & 0.78 & 53.7 \\
\hline $\begin{array}{l}\text { Total number of working broiler farms at } \\
\text { Matrouh level }\end{array}$ & 29.4 & 22.9 & 6.4 & 0.73 & 41.5 \\
\hline
\end{tabular}

Source: Table (1)

\section{Calculation of A biosecurity Indicator System for Every Farm}

The biosecurity indicator system was calculated from 36 subbiosecurity indicators elicited from the respondents through a survey. The first step in generating a biosecurity indicator system was to score each individual sub-biosecurity indicator, for example, the source of poultry feed, the actions taken to minimize pest and rodent entry, or the number and type of signs installed around the farm. This is similar to the approaches of Fraser et al. (2009), who used a similar scoring system.

Most of the indicators had been allocated scores ranging from 1 to 3 ( 1 being low biosecurity level and 3 being high biosecurity level). For example was more biosecure to purchase farm inputs (indicators $1 \mathrm{~B}$ to $1 \mathrm{~F}$ ) direct from the contractor or feed company (a score of 3) rather than from a poultry shop (score 2) or another farmer (score 1). Several indicators had a broader range of responses, and therefore a broader range of scores. One of these was parking and vehicle washing. Low biosecurity concerning this indicator (a score of 1) mean there was no designated parking area, no car wash area and no high-pressure pump available to clean vehicles as they enter. High biosecurity (a score of 7), indicated that a car park, car wash area and pressure pump were present. Scores of 2 to 6 indicated the presence of some, but not all of these facilities.

Table (3) shows that, the majority of the respondents were middleaged, married, read and write form of education, had families with more than seven members, majority of the respondents were the manager of the farms, had poultry as the main occupation, were working full time in the poultry

Egyptian J. Desert Res., 68, No. 2, 173-186 (2018) 
farms and majority of the respondents had a 3000-5000 LE as a non-poultry income.

Table (3). Distribution of respondents by their personal and socio-economic characteristics.

\begin{tabular}{|c|c|c|c|}
\hline Variable & Description & Frequency & Percentage \\
\hline \multirow{4}{*}{ Age } & Younger than 30 years & 15 & 23.0 \\
\hline & Between $30-60$ years & 45 & 69.3 \\
\hline & Older than 60 years & 5 & 7.7 \\
\hline & Total & 65 & 100 \\
\hline Variable & Description & Frequency & Percentage \\
\hline \multirow{7}{*}{ Education Status } & Non education & 10 & 15.4 \\
\hline & Read and write & 35 & 53.8 \\
\hline & Primary education & - & - \\
\hline & Preparatory education & 5 & 7.7 \\
\hline & Technical education & 10 & 15.4 \\
\hline & University education & 5 & 7.7 \\
\hline & Total & 65 & 100 \\
\hline \multirow{5}{*}{ Marital Status } & Married and have children & 65 & 100 \\
\hline & Married and has no children & - & - \\
\hline & Single & - & - \\
\hline & Divorced or widowed & - & - \\
\hline & Total & 65 & 100 \\
\hline \multirow{4}{*}{$\begin{array}{l}\text { Number of family } \\
\text { members }\end{array}$} & Less than five members & 5 & 7.7 \\
\hline & Between 5-7 members & 25 & 38.5 \\
\hline & More than seven members & 35 & 53.8 \\
\hline & Total & 65 & 100 \\
\hline \multirow{4}{*}{$\begin{array}{l}\text { Farm ownership } \\
\text { type (\%) }\end{array}$} & Owner & 20 & 30.8 \\
\hline & Manager & 35 & 53.8 \\
\hline & Owner and manager & 10 & 15.4 \\
\hline & Total & 65 & 100 \\
\hline \multirow{3}{*}{$\begin{array}{l}\text { Farm head -main } \\
\text { occupation }\end{array}$} & Poultry as the main occupation & 38 & 58.4 \\
\hline & Other occupation & 27 & 41.6 \\
\hline & Total & 65 & 100 \\
\hline \multirow{3}{*}{$\begin{array}{l}\text { Farm head - } \\
\text { working time on } \\
\text { the farm }\end{array}$} & Working full time & 38 & 58.4 \\
\hline & Working part-time & 27 & 41.6 \\
\hline & Total & 65 & 100 \\
\hline \multirow{4}{*}{$\begin{array}{l}\text { Non-poultry } \\
\text { income per farm }\end{array}$} & Less than $3000 \mathrm{LE}$ & 25 & 38.4 \\
\hline & Between 3000-5000 LE & 30 & 46.1 \\
\hline & More than $5000 \mathrm{LE}$ & 10 & 15.5 \\
\hline & Total & 65 & 100 \\
\hline
\end{tabular}

Source: questionnaire data, 2018

Egyptian J. Desert Res., 68, No. 2, 173-186 (2018) 
Table (4) shows that, all the farms had one shed, the majority of farms had an average capacity of shed of about 5000-6000 birds. There were about three commercial farms within $1 \mathrm{~km}$. The average distance to the main road was $5 \mathrm{~km}$, the distance to nearest house was $3-5 \mathrm{~km}$, the distance to nearest live bird market was less than $3 \mathrm{~km}$, the distance to nearest Neighbor's shed was less than $3 \mathrm{~km}$ and the distance to nearest feed shed also was less than $3 \mathrm{~km}$.

Table (4). Distribution of farms by the size of broiler farms.

\begin{tabular}{|c|c|c|c|}
\hline Variable & Description & Frequency & Percentage \\
\hline \multirow{3}{*}{ Number of sheds (unit) } & One shed & 65 & 100 \\
\hline & More than one shed & - & - \\
\hline & Total & 65 & 100 \\
\hline \multirow{4}{*}{$\begin{array}{l}\text { The average capacity of } \\
\text { a shed (bird) }\end{array}$} & Less than 5000 & 3 & 15.4 \\
\hline & Between 5000-6000 & 55 & 53.8 \\
\hline & More than 6000 & 8 & - \\
\hline & Total & 65 & 100 \\
\hline Variable & Description & Frequency & Percentage \\
\hline \multirow{4}{*}{$\begin{array}{l}\text { No. of other } \\
\text { commercial farms } \\
\text { within } 1 \mathrm{~km}\end{array}$} & Less than 3 & 13 & 100 \\
\hline & Between 3-5 & 44 & - \\
\hline & More than 5 & 8 & - \\
\hline & Total & 65 & 100 \\
\hline \multirow{4}{*}{$\begin{array}{l}\text { Distance to main road } \\
(\mathrm{km})\end{array}$} & Less than 3 & 5 & 7.7 \\
\hline & Between 3-5 & 25 & 38.5 \\
\hline & More than 5 & 35 & 53.8 \\
\hline & Total & 65 & 100 \\
\hline \multirow{4}{*}{$\begin{array}{l}\text { Distance to nearest } \\
\text { house }(\mathrm{km})\end{array}$} & Less than 3 & 23 & 30.8 \\
\hline & Between 3-5 & 35 & 53.8 \\
\hline & More than 5 & 7 & 15.4 \\
\hline & Total & 65 & 100 \\
\hline \multirow{4}{*}{$\begin{array}{l}\text { Distance to nearest live } \\
\text { bird market }(\mathrm{km})\end{array}$} & Less than 3 & 3 & 66.2 \\
\hline & Between 3-5 & 19 & 33.8 \\
\hline & More than 5 & 43 & \\
\hline & Total & 65 & 100 \\
\hline \multirow{4}{*}{$\begin{array}{l}\text { Distance to nearest } \\
\text { Neighbor's shed }(\mathrm{km})\end{array}$} & Less than 3 & 39 & 66.2 \\
\hline & Between 3-5 & 20 & 33.8 \\
\hline & More than 5 & 6 & \\
\hline & Total & 65 & 100 \\
\hline \multirow{4}{*}{$\begin{array}{l}\text { Distance to nearest feed } \\
\text { shed }(\mathrm{km})\end{array}$} & Less than 3 & 65 & 100 \\
\hline & Between 3-5 & - & - \\
\hline & More than 5 & - & - \\
\hline & Total & 65 & 100 \\
\hline
\end{tabular}

Source: questionnaire data, 2018

Egyptian J. Desert Res., 68, No. 2, 173-186 (2018) 


\section{Factors Affecting the Applicable Level of Biosecurity Activities in Poultry Farms}

Van Steenwinkel (2011) and Siekkinen et al. (2012) identified the factors that influence the applying level of biosecurity activities or desire to implement a better level of biosecurity activities and they can be classified as following:

- Respondents characteristics and,

- Farm characteristics

\subsection{Characteristics of respondents}

Table (5) shows that the regression model indicated that the respondents' characteristics that significantly influenced the applicable level of farm biosecurity measures were age and education level of the farm head. The older and more educated respondents, the higher applicable level of biosecurity activities. Older respondents might have more control over their decision making and more confidence to make improved managerial decisions. More educated respondents might be more able to understand the biosecurity concept and saw the potential importance of implementing these management changes. The number of respondents' family members had a significant positive influence on the applicable level of biosecurity activities in broiler farms. While it was expected that the higher the number of family members might lead to a lower applicable level of biosecurity activities. This analysis showed that the higher the number of respondents' family members, the higher the applicable level of biosecurity activities. It might be that respondents understand the risks posed by many people having access to their farm and found it easier to insist on good biosecurity activities with their family members as opposed to hired labour. Broiler farms tended to be smaller hence can rely on family labour rather than hired labour. Broiler farms were also probably less labour intensive. Non-poultry income had a negative effect on the applicable level of biosecurity activities on broiler farms. That was, the higher level of non-poultry income the lower applicable level of biosecurity activities, respondents who were more dependent on the income from farm production were more likely to attempt to protect their assets and maybe improve efficiency than were respondents who had other priorities.

\subsection{Characteristics of farms}

There were two variables, farm size and distance of farm to neighbour's poultry that had a positive influence on the applicable level of biosecurity activities in broiler farms. As expected the larger the farm (in farm size, not capacity) the higher the applicable level of biosecurity activities. It might be that the respondents with larger farms understood the increased risk of disease entry and have the resources to do something about it. The distance to a neighbour's poultry influenced a respondents' decision 
to implement biosecurity, but probably not in the way that was expected. It was expected that the closer the farm is to a source of disease. In this case, a neighbour's farm, the higher the attempt to minimize the ability of the disease to spread. However, this analysis has shown that the further the poultry farm from the source of risk, the higher the applicable level of biosecurity measures. Another factor influencing the applicable level of biosecurity activities was the distance from the farm to the nearest road. This factor had the same positive significance as did distance from neighbours. It appeared that respondents, who were close to essential sources of risk such as neighboring farms and roads may believed that it was a waste of time trying to reduce the risk, while respondents who had a natural advantage believed that the risk was manageable and worth investing in, respondents who had more and larger farms applied higher levels of biosecurity activities. This was because larger-scale broiler farms needed to avoid the potentially large losses caused by disease outbreaks, respondents were prepared to invest more time and money to minimize the risk of loss.

Table (5). Factors affecting the applicable level of biosecurity activities in poultry farms.

\begin{tabular}{lc}
\hline Variable & Coefficient \\
\hline Characteristics of farmers & \\
\hline Age & $0.5320^{*}$ \\
Education & $0.7310^{*}$ \\
Non-poultry income & $-0.0680^{*}$ \\
Number of Family members & $2.8320^{*}$ \\
Characteristics of farm: & \\
\hline Farm size & $0.0530^{*}$ \\
Distance to neighbours poultry & $0.0690^{*}$ \\
Distance to road & $0.0060^{*}$ \\
Number of farms & $2.6500^{*}$ \\
Average farm capacity & $0.0243^{*}$ \\
\hline
\end{tabular}

*Significant at 5\% level

Source: questionnaire data, 2018

\section{REFERENCES}

Banshi, S. (2010). Poultry production, management and biosecurity measures. The Journal of Agriculture and Environment, 11: 120-125.

Bhattarai, T.C. (2008). Poultry production scenario of Nepal. Paper presented in Poultry Entrepreneurs' Forum, Kathmandu with collaboration with World Poultry Science Association.

Fraser, R., N. Williams, L. Powell and A. Cook (2009). Reducing campylobacter and salmonella infection: Two studies of the economic

Egyptian J. Desert Res., 68, No. 2, 173-186 (2018) 
cost and attitude to adoption of on-farm biosecurity. Zoonoses and Public Health, 57: 109-115.

Siekkinen, K., J. Heikkila, N. Tammiranta and H. Rosengren (2012). Measuring the costs of biosecurity on poultry farms: A case study in broiler production in Finland. Acta Veterinaria Scandinavica, 54 (12).

Van Steenwinkel, S. (2011). Assessing biosecurity practices, movements and densities of poultry sites across Belgium, resulting in different farm risk-groups for infectious disease introduction and spread. Preventive Veterinary Medicine, 98 (4): 259-270.

Appendix (1). Individual farm biosecurity indicators.

\begin{tabular}{|c|c|c|c|}
\hline \multirow[t]{2}{*}{ Stage } & \multicolumn{3}{|c|}{ Level of biosecurity } \\
\hline & Low & Medium & High \\
\hline \multicolumn{4}{|l|}{ 1. Farm inputs } \\
\hline 1A. Type of poultry feed & $\begin{array}{l}\text { Home produced feed, } \\
\text { home produced feed and } \\
\text { commercial pellets, a } \\
\text { mixture of all feed types }\end{array}$ & $\begin{array}{l}\text { Purchased grain, } \\
\text { purchased grain } \\
\text { and commercial } \\
\text { pellets }\end{array}$ & Commercial feed \\
\hline 1B. Source of concentrate & $\begin{array}{l}\text { Spot market, other } \\
\text { smallholders }\end{array}$ & Poultry shop & $\begin{array}{l}\text { Contract company, direct } \\
\text { from feed company }\end{array}$ \\
\hline $\begin{array}{l}\text { 1C. Source of grain and } \\
\text { other ingredients }\end{array}$ & Other farms & Poultry shop & $\begin{array}{l}\text { Contract company, direct } \\
\text { from feed company, spot } \\
\text { market }\end{array}$ \\
\hline 1D. Source of supplements & $\begin{array}{l}\text { Spot market, other farms, } \\
\text { do not know }\end{array}$ & $\begin{array}{l}\text { Poultry shop, } \\
\text { Don not purchase }\end{array}$ & $\begin{array}{l}\text { Contract company, direct } \\
\text { from feed or drug } \\
\text { company }\end{array}$ \\
\hline 1E. Source of litter & $\begin{array}{l}\text { Spot market, other farms, } \\
\text { do not know }\end{array}$ & $\begin{array}{l}\text { Poultry shop, rice } \\
\text { mill, do not } \\
\text { purchase }\end{array}$ & Contract company \\
\hline $\begin{array}{l}\text { 1F. Poultry drinking water } \\
\text { chlorinated }\end{array}$ & No, do not know & Sometimes & Yes \\
\hline \multicolumn{4}{|l|}{ 2. Traffic onto the farm } \\
\hline $\begin{array}{l}\text { 2A. Permission for a } \\
\text { collector to enter a farm }\end{array}$ & $\begin{array}{l}\text { Contract company, } \\
\text { technical support, poultry } \\
\text { shop, collectors, no } \\
\text { decision }\end{array}$ & & $\begin{array}{l}\text { Owner, manager, owner }+ \\
\text { manager, manager } \\
\text { suggests owner decides }\end{array}$ \\
\hline \multicolumn{4}{|l|}{$\begin{array}{l}\text { 2B. Permission for relative } \\
\text { of the laborer to enter a } \\
\text { farm }\end{array}$} \\
\hline \multicolumn{4}{|l|}{$\begin{array}{l}\text { 3. Level of biosecurity at } \\
\text { the farm gate }\end{array}$} \\
\hline 3A. Fences and locks & $\begin{array}{l}\text { No secure boundary fence, } \\
\text { no locks on gates }\end{array}$ & $\begin{array}{l}\text { Two rankings } \\
\text { between these low } \\
\text { and high options }\end{array}$ & $\begin{array}{l}\text { Secure boundary fences, } \\
\text { locks on all gates, gates } \\
\text { locked at all times }\end{array}$ \\
\hline
\end{tabular}




\begin{tabular}{|c|c|c|c|}
\hline \multicolumn{4}{|l|}{ Cont. Appendix (1). } \\
\hline 3B. Number of entrances & More than 3 & 2 & 1 \\
\hline $\begin{array}{l}\text { 3C. Parking and vehicle } \\
\text { washing }\end{array}$ & $\begin{array}{l}\text { No parking area, car wash } \\
\text { area or high-pressure } \\
\text { pump }\end{array}$ & $\begin{array}{l}\text { Five rankings } \\
\text { between these low } \\
\text { and high options }\end{array}$ & $\begin{array}{l}\text { Dedicated parking area, } \\
\text { car wash for all vehicles } \\
\text { entering the farm, high- } \\
\text { pressure pump spray }\end{array}$ \\
\hline 3D. Signs around perimeter & No signs & $\begin{array}{l}\text { Two rankings } \\
\text { between these low } \\
\text { and high options }\end{array}$ & $\begin{array}{l}\text { A high number of signs } \\
\text { per farm area, sign } \\
\text { instructing report to an } \\
\text { office }\end{array}$ \\
\hline 3E. Footbaths at farm gates & No footbath at farm entry & $\begin{array}{l}\text { Two rankings } \\
\text { between these low } \\
\text { and high options }\end{array}$ & $\begin{array}{l}\text { All entries have footbaths, } \\
\text { water and detergent } \\
\text { regularly changed }\end{array}$ \\
\hline $\begin{array}{l}3 \mathrm{~F} \text {. Family living off-farm; } \\
\text { requirements when entering } \\
\text { a farm }\end{array}$ & $\begin{array}{l}\text { Nothing, some of these } \\
\text { things, do not know }\end{array}$ & & $\begin{array}{l}\text { Register at an office, } \\
\text { visitor log book, use } \\
\text { protective clothing, enter } \\
\text { through a shower, park } \\
\text { outside the farm, answer } \\
\text { about previous farm visits } \\
\text { that day, scrub/change } \\
\text { boots, wash hands, } \\
\text { vehicle, equipment }\end{array}$ \\
\hline \multicolumn{4}{|l|}{ 3G. Non-family employees } \\
\hline \multicolumn{4}{|l|}{$\begin{array}{l}3 \mathrm{H} \text {. Visitors, non- } \\
\text { employees living off-farm; } \\
\text { requirements when entering } \\
\text { a farm }\end{array}$} \\
\hline $\begin{array}{l}\text { 3I. Shower and change } \\
\text { room for visitors and } \\
\text { employees }\end{array}$ & Yes, but not used, no & & Yes and used \\
\hline $\begin{array}{l}\text { 3J. Use of own cages when } \\
\text { selling live chickens }\end{array}$ & $\begin{array}{l}\text { Yes, sometimes, do not } \\
\text { know }\end{array}$ & No & \\
\hline $\begin{array}{l}3 \mathrm{~K} \text {. Clean cages and } \\
\text { equipment returning from } \\
\text { market }\end{array}$ & $\begin{array}{l}\text { No, sometimes, do not } \\
\text { know }\end{array}$ & & $\begin{array}{l}\text { Yes, no equipment comes } \\
\text { back to the farm }\end{array}$ \\
\hline \multicolumn{4}{|l|}{$\begin{array}{l}\text { 4. Level of biosecurity } \\
\text { between farm gate and } \\
\text { shed }\end{array}$} \\
\hline $\begin{array}{l}\text { 4A. Feed shed sealed } \\
\text { against rodents and birds }\end{array}$ & $\begin{array}{l}\text { No, sometimes, do not } \\
\text { know }\end{array}$ & & Fully sealed \\
\hline $\begin{array}{l}\text { 4B. Water overflow } \\
\text { management }\end{array}$ & $\begin{array}{l}\text { Water lying, no action } \\
\text { taken }\end{array}$ & $\begin{array}{l}\text { Two rankings } \\
\text { between these low } \\
\text { and high options }\end{array}$ & $\begin{array}{l}\text { No water lying around, } \\
\text { action taken }\end{array}$ \\
\hline 4C. Spilt feed management & $\begin{array}{l}\text { Yes, sometimes, do not } \\
\text { know }\end{array}$ & & No \\
\hline
\end{tabular}

Egyptian J. Desert Res., 68, No. 2, 173-186 (2018) 


\begin{tabular}{|c|c|c|c|}
\hline Cont. Appendix (1). & & & \\
\hline $\begin{array}{l}\text { 4D. Village chickens } \\
\text { management }\end{array}$ & Yes, always around shed & Sometimes & No \\
\hline $\begin{array}{l}\text { 5. Level of biosecurity at } \\
\text { the shed door }\end{array}$ & & & \\
\hline $\begin{array}{l}\text { 5A. Construction of shed } \\
\text { walls }\end{array}$ & Other & Plastic & Concrete, netting \\
\hline $\begin{array}{l}\text { 5B. Shed locked at all } \\
\text { times }\end{array}$ & $\begin{array}{l}\text { No, sometimes, do not } \\
\text { know }\end{array}$ & & Yes \\
\hline 5C. Signs at the shed doors & No, do not know & Some & Yes, all \\
\hline $\begin{array}{l}\text { 5D. Concrete footbath at } \\
\text { shed entrances }+ \\
\text { disinfectant }\end{array}$ & No, do not know & Some & Yes, all \\
\hline $\begin{array}{l}\text { 5E. Wild birds and rodents } \\
\text { entering the shed }\end{array}$ & $\begin{array}{l}\text { Yes, sometimes, do not } \\
\text { know }\end{array}$ & & No \\
\hline $\begin{array}{l}\text { 5F. Action to prevent } \\
\text { entry of wild birds and } \\
\text { rodents }\end{array}$ & Nothing & $\begin{array}{l}\text { Built off the } \\
\text { ground, rat baits, } \\
\text { scarecrows, a fence } \\
\text { around shed, cut } \\
\text { trees }\end{array}$ & Bird proof netting \\
\hline 6. Traffic into shed & & & \\
\hline $\begin{array}{l}\text { 6A. Number of employees } \\
\text { working in a shed }\end{array}$ & $>2$ & $0-2$ & 0 \\
\hline $\begin{array}{l}\text { 6B. Number of people } \\
\text { entering sheds }\end{array}$ & $>2$ & $0-2$ & 0 \\
\hline $\begin{array}{l}\text { 7. Susceptibility of broiler } \\
\text { flock }\end{array}$ & & & \\
\hline $\begin{array}{l}\text { 7A. The decision on the } \\
\text { broiler vaccination program }\end{array}$ & Other & $\begin{array}{l}\text { Manager suggests, } \\
\text { the owner decides, } \\
\text { a contract company }\end{array}$ & $\begin{array}{l}\text { An owner, manager, } \\
\text { owner and manager }\end{array}$ \\
\hline $\begin{array}{l}\text { 7B. Vaccinate broilers for } \\
\text { Newcastle Disease (ND) }\end{array}$ & No & & Yes \\
\hline $\begin{array}{l}\text { 7C. Vaccinate broilers for } \\
\text { HPAI }\end{array}$ & No & & Yes \\
\hline $\begin{array}{l}\text { 7D. Source of vaccines for } \\
\text { broilers }\end{array}$ & $\begin{array}{l}\text { Spot market, poultry shop, } \\
\text { other smallholders, do not } \\
\text { purchase }\end{array}$ & Contract company & $\begin{array}{l}\text { The government, direct } \\
\text { from a drug company }\end{array}$ \\
\hline
\end{tabular}

Egyptian J. Desert Res., 68, No. 2, 173-186 (2018) 


\title{
العو امل المؤثرة على مستوى تطبيق أنثطة الأمن الحيوي بمزارع دواجن جمئ التسمين في محافظة مطروح، جمهورية مصر ألعربئ العربية
}

\author{
سهى مصطفى الايب* وداليا السيد أبو زيد

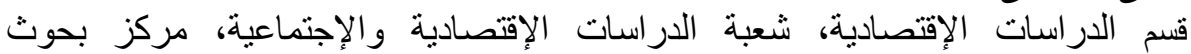 \\ الصحر اء، المطرية، القاهرة، مصر
}

يهدف البحث إلى تحديد العوامل المؤثرة على مستوى تطبيق أنشطة الأمن الحيوي في

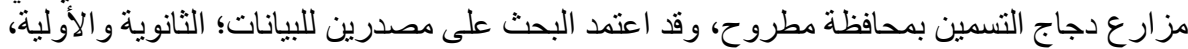

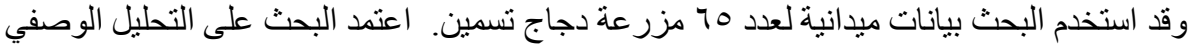

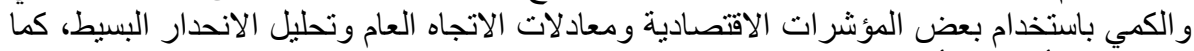

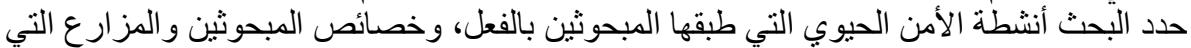

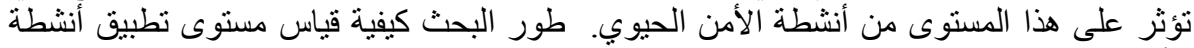

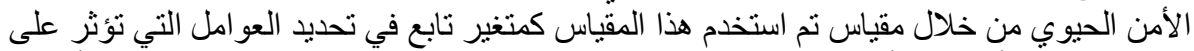

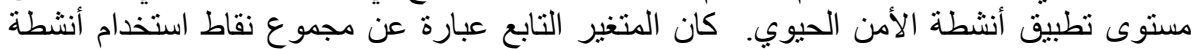

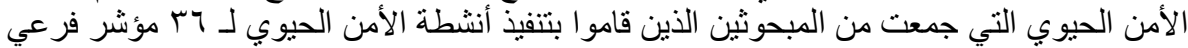

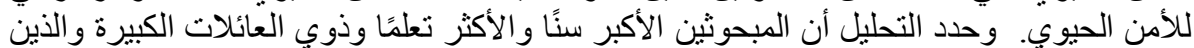

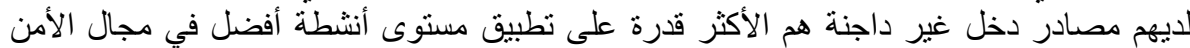

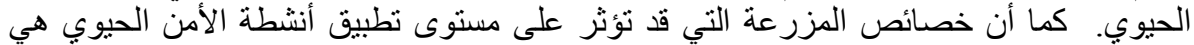

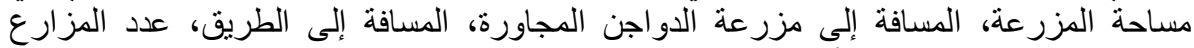
ومتوسط سعة المزرعة مهمة أيضًا.

Egyptian J. Desert Res., 68, No. 2, 173-186 (2018) 